\title{
Bioline
}

for

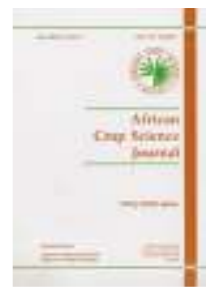

African Crop Science Journal

AFRICAN CROP SCIENCE SOCIETY

ISSN: $1021-9730$

VOL. 10, NUM. 1, 2002, PP. 31-38

African Crop Science Journal, Vol. 10. No. 1, 2002, pp. 31-38

\section{EFFECT OF PLANT POPULATION DENSITY ON THE GROWTH AND YIELD OF SORGHUM VARIETIES GROWN ON A VERTISOL}

\author{
R. Tabo, O.G. Olabanji ${ }^{1}$, O. Ajayi ${ }^{2}$ andFlower $^{3}$ \\ ICRISAT, Bamako, BP 320, Bamako, Mali \\ ${ }^{1}$ Lake Chad Research Institute (LCRI), PMB 1293, Maidugiri, Nigeria \\ ${ }^{2}$ ICRISAT C/o IITA, Sabo Bakin Zuwo Road, PMB 3491, Kano, Nigeria \\ ${ }^{3} 209$ Bathurst St, Condobolin 2877, Australia
}

(Received 2 June, 1999; accepted 24 November, 2001)

Code Number: cs02004

\begin{abstract}
Sorghum (Sorghum bicolor (L.) Moench) is an important crop that is usually grown on the Vertisols of north eastern Nigeria during the dry season. The crop is grown on soils with residual moisture, and thus exposing it to terminal drought stress. Improvement of resource use efficiency and yields is probably possible through the use of appropriate plant densities. Field trials were therefore conducted to study the effects of four plant densities, varying from 2.0 to 12.5 plants $\mathrm{m}^{-2}$ on water and radiation use and performance of two Masakwa sorghum varieties grown on a Vertisol under residual soil moisture conditions. At higher plant densities the locally adapted Nigerian variety, Bulwalana produced higher grain yields than the selection from Cameroun, Bourgouri-28. It also had more efficient water use and better light interception. At low plant densities, Bourgouri-28 yielded higher than Bulwalana. Leaf area index and radiation interception increased with increasing plant density. Stem borer incidence decreased with increasing plant density. More stem borer holes and stem tunnelling were recorded in Bulwalana than in Bourgouri-28. Covered kernel smut [Sporisorium sorghi (Ehrenberg) Link] appeared to be a potentially serious disease of the crop. The study showed that the performance of the crop can be improved through manipulation of plant population and use of early maturing cultivars.
\end{abstract}

Key Words: Sorghum bicolor, transplanted sorghum, water use efficiency, yield

\section{RÉSUMÉ}

Le sorgho (Sorghum bicolor (L.) Moench) est une culture importante sur les Vertisols de la partie nord est du Nigéria pendant la saison sèche. Planté généralement à cause de l'humidité residuelle, le sorgho souffre souvent du stress hydrique de fin de cycle. L'amélioration de l'utilisation efficace des ressources et des rendements est possible à travers l'usage des densités appropriées des plantes. Les essais de champ ont été 
ménés pour étudier les effets de quatre densités des plantes, variant entre 2.0 et 12.5 plantes $\mathrm{m}^{-2} \mathrm{sur}$ l'utilisation de l'eau, de la radiation et sur la performance de deux variétés de sorgho Masakwa cultivées sous des conditions d'humidité résiduelle. A des densités de plantes élévées, la variété Nigériane localement adaptée, Bulwalana a produit un rendement en grains plus élévé que la sélection du Cameroun, Bougouri-28. Elle avait aussi une utilisation plus efficace de l'eau et une meilleure interception de la radiation. Aux densités basses, Bougouri-28 a eu un rendement plus élévé que celui de Bulwalana. La surface foliaire et l'interception de la radiation ont augmenté avec la densité des plantes. L'incidence des foreurs des tiges a diminué avec l'augmentation des densités des plantes. Un plus grand nombre des trous des foreurs des tiges et des percements des tiges ont été enregistrés sur Bulwalana que sur Bourgouri-28. Le charbon couvert [Sporisorium sorghi (Ehrenberg) Link] apparait comme une maladie potentielle sérieuse de ce sorgho. Cette étude a montré que la performance de ce sorgho peut être améliorée en manipulant la densité des plantes et en utilisant des cultivars adaptés et précoces.

Mots Clés: Sorghum bicolor, foreur des tiges, efficacité d'utilisation de l'eau, rendement

\section{INTRODUCTION}

Sorghum (Sorghum bicolor) commonly refered to as Masakwa sorghum is the major crop grown on the Vertisols of north eastern Nigeria during the post rainy season. In northern Cameroon, this dry season sorghum in called Muskwari and represents $25-30 \%$ of the total sorghum production (Djonnewa and Dangi, 1988). In Chad it is also an important cereal crop with good grain quality, and is locally known as Berbere. The crop matures in the dry season and usually escapes insect pests and diseases infestations compared with the rainy season crop.

Vertisols on which this crop is grown have an agroecological potential for food production above their present level of use (Kanwar and Virmani, 1987). They have high water holding and cation exchange capacities. However, because of their high clay content, poor drainage and low hydraulic conductivity in the swollen state, Vertisols are very hard when dry and extremely sticky and difficult to manage when the rains commence (Swindale and Miranda, 1984). They are therefore largely under utilised by farmers in the tropics and are left under fallow during the rainy season. During the dry season, it is common practice for farmers to grow Masakwa sorghum on these soils.

Masakwa sorghum is tranplanted and grown on soils with residual moisture content during the dry period (September to February). Though soil moisture may be adequate in deeper layers, the plant may not be able to extract it due to low root density in those layers (Russell, 1980). Thus, the crop is often exposed to drought stress. From available literature, the major constraint to increased production of this crop is soil moisture availability (Barrault et al., 1972). Farmers traditionally grow the crop at low plant densities $(10,000$ to 14,000 plants ha ${ }^{-1}$ ) to reduce the risk of water stress (Rao et al., 1988; Njomaha and Kamuanga, 1991; Carsky, 1993). The yields are in general low, ranging from 300 to $800 \mathrm{~kg} \mathrm{ha}^{-1}$ depending on the season and variety used (Djonnewa and Dangi, 1988).

Limited information is available on the physiological and morphological response of the crop to its environment (especially biotic factors). Understanding factors such as plant density which are associated with resource use and biotic stress would help in the genetic improvement of the crop and the development of improved management practices for increased and sustainable grain production on these Vertisols.

The objective of this study was therefore to examine the effects of plant density on water and radiation use, growth and yield of two Masakwa sorghum varieties.

\section{MATERIALS AND METHODS}

Field experiments were conducted at the Lake Chad Research Institute, Ngala, Borno State, Nigeria $\left(12^{\circ} 22^{\prime}\right.$ $\mathrm{N}, 14^{\circ} 12^{\prime} \mathrm{E}$ ) during the post rainy seasons of $1991 / 1992$ and $1992 / 1993$. The soil is classified as very fine, clayey, montmorilloric, calcareous, hyperthermic member of the family of typic Pallusterts (USDA taxonomy). The available water holding capacity in the top $150 \mathrm{~cm}$ is about $200 \mathrm{~mm}$. These Vertisols are developed on Chad Lagoonal clays underlain by aeolian sands. Their salient feature is the high clay content (up to $40 \%$ ) which cause them to have deep cracks upon drying. A randomised complete block design with three replicates was used. There were eight $12 \times 9 \mathrm{~m}$ plots in each replication. The net plot size was $9 \times 3 \mathrm{~m}$ 
$\left(27 \mathrm{~m}^{2}\right)$. The plots were separated by $1 \mathrm{~m}$ alleys with a discard of $1 \mathrm{~m}$ at the end of each row.

Crop management. Land preparation was done manually. Grasses and shrubs were removed from the field using large sickles. Fourty days old seedlings of one local variety from Nigeria (Bulwalana) and one local selection from Cameroun (Bourgouri-28) were transplanted on 26 September 1991 and on 7 October 1992. Earth bunds were formed using shovels and the field was flood irrigated by pumping water from a nearby reservoir. Irrigation water was applied to ensure adequate plant stand and to recharge the soil profile to field capacity. There were four plant densities namely, 2.0, 5.6, 8.0 and 12.5 plants $\mathrm{m}^{-2}$. To ensure adequate moisture in the soil profile for crop growth, the field was irrigated to field capacity. Data on soil moisture uptake, growth analysis, radiation interception and yields were measured (as described below) and recorded.

Soil moisture uptake. Two access tubes were installed in each plot to a depth of $1.35 \mathrm{~m}$. Volumetric water content was measured at $0.15 \mathrm{~m}$ interval from 0.3 to 1.35 , every 14 days starting from 35 up to 106 days after transplanting (DAT), using a Wallinford neutron probe. Gravimetric measurements were taken from the top $0.3 \mathrm{~m}$ of the soil at the time of probe readings. Water use efficiency (WUE) was determined as the ratio of grain yield per unit area $\left(\mathrm{kg} \mathrm{ha}^{-1}\right)$ to total water use $(\mathrm{mm})$, which was determined from the probe and gravimetric measurements. Evaporation and deep drainage were assumed to be negligible.

Growth analysis. Between 35 and 106 days after transplanting sorghum, plant samples (at least 6 plants per treatment) were collected fortnightly from each plot. Each plot samples were separately separated into leaves, stems and panicles. Leaf area of nine representative leaves, three from the top, three from the middle, and three from the base of the plant was measured using a $\mathrm{LI}-\mathrm{COR}^{\mathrm{R}}$ model 3100 leaf area meter. All the plant parts were oven dried at $60^{\circ} \mathrm{C}$ and the dry weights recorded. Total leaf area per plant was calculated as the product of total leaf weight of the plant and specific leaf area (SLA). It was considered to be the ratio of the leaf area to the dry weight of the nine leaves in the subsample. Leaf area index (LAl) was calculated by dividing total leaf area of the plants in each sample by the ground area covered.

Radiation interception. Radiation interception was measured with a ceptometer every fortnight between 1100 and 1300 hours starting 35 to 106 days after transplanting sorghum. The light readings were taken across two rows in the net plot at points marked by permanently fixed pegs. At each fixed point two readings were taken: one above the crop and the other below the canopy. There were five fixed points per plot for a total of 10 light readings. The difference between the average of the five readings taken above the canopy and those taken below it was multiplied by 100 to obtain percent radiation intercepted per plot.

Yield. At physiological maturity panicles were harvested from net plots, dried and threshed for the determination of grain yield and grain size.

Data analysis. All data collected were subjected to (ANOVA) analysis of variance using GENSTAT statistical package (Lane and Payne, 1996).

\section{RESULTS}

Water use efficiency. In both years, at high plant density ( 8.0 and 12.5 plants $\left.\mathrm{m}^{-2}\right)$, Bulwalana had greater WUE than Bourgouri-28, except at 12.5 plants $\mathrm{m}^{-2}$ in 1992/93, whereas at the lower plant densities ( 2.0 and 5.6 plants $\left.\mathrm{m}^{-2}\right)$, WUE did not differ among the two varieties (Fig. 1). In 1991/92, WUE of the two varieties decreased with increasing plant density but that of Bulwalana increased at plant density of 12.5 plants $\mathrm{m}^{-2}$. In 1992/93 WUE of the two cultivars did not have any consistent trend across the different densities. The WUE of Bulwalana was highest at 8.0 plants $\mathrm{m}^{-2}$.

Leaf area index. As expected, LAI of both cultivars increased with increasing density in both years (Fig. 2). Overall Bourgouri-28, the taller and late maturing variety, had a higher LAI than Bulwalana at the four plant densities. At the lowest density, Bougouri-28 maintained a LAI higher than that of Bulwalana from vegetative to reproductive states, which explained in part, the differences in radiation interception between the two varieties.

Radiation interception. For both years, radiation interception of the two varieties was in general greater at the high than at low plant densities, though no consistent trend was observed throughout the growth period (Fig. 3). Bourgouri-28 intercepted more radiation than Bulwalana at low plant density throughout the season while Bulwalana performed better 
at high plant density.

Total dry matter and grain yield. Total dry matter production of the two cultivars increased as plant density increased from 2.0 to 12.5 plants $\mathrm{m}^{-2}$ in both years (Fig. 4). Bourgouri-28, the late maturing and taller variety produced more total biomass than Bulwalana, the early and short maturing variety.

In 1991/92, the local Nigeria, variety, Bulwalana yielded more gain than the selection from Cameroun, Bourgouri-28 at high plant density (12.5 plants $\mathrm{m}^{-2}$ ) (Table 1$)$. However, at the lowest density $\left(2.0\right.$ plants $\left.\mathrm{m}^{-2}\right)$, Bourgouri-28 out yielded Bulwalana. The two varieties gave the same grain yields at a density of 5.6 plants $\mathrm{m}^{-2}$. In 1992/93, Bulwalana produced more grain yields than Bourgouri-28 at 8.0 plants $\mathrm{m}^{-2}$ whereas at low densities, Bourgouri-28 had higher grain yields than Bulwalana. In general, grain yields of Bulwalana increased with increasing density while that of Bourgouri-28 decreased as plant density increased. There was no significant difference in seed size for the two varieties, which

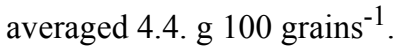

\section{DISCUSSION}

Resource use, growth and yield. In this study, the field was irrigated and the soil profile was recharged to field capacity to ensure that there was adequate moisture in the soil profile for crop growth. The performance of the crop under these conditions would not therefore be affected by the availability of moisture in the early stages of crop growth but by the extent to which the crop had access to that moisture and the efficiency with which it used the water.

Thus, the better response of Bulwalana to higher plant densities could be attributed to its higher water use efficiency at those densities. As a response to greater competition for water due to the high plant density, Bulwalana must have developed a deeper and more extensive root system to tap moisture from deeper layers of the soil profile. Furthermore, Bulwalana responded positively to increased plant density probably because it is shorter and matures earlier than Bourgouri-28. Under conditions of reduced water stress due to low plant density, Bourgouri-28 used more water than Bulwalana. This did not, however, translate into significantly better water use efficiency and thus, higher grain yields.

In addition to use of improved cultural practices, the amount of rainfall during the crop season, which influences the amount of moisture stored in the soil profile, is an important factor in the performance of the crop grown on Vertisols during the dry season. For instance, Barrault et al. (1972) reported that early rainy season plowing which enhanced infiltration and retention of rainfall, thereby increasing soil profile moisture at the time of transplanting by about $10 \%$ resulted in a grain yield increase of $30 \%$.

Since the availability of water to post rainy season sorghum is finite it is critical to save enough water for use during grain filling (Passioura, 1983). However, in deeper soils it is desirable for the plants to extract water fully from the upper layers early in the season, to ensure maximum productivity (Seetharama et al., 1990). This implies that plant densities should be high enough to enable plants extract as much water as possible from the soil profile, but not too high to exhaust it before the grain filling stage. This study demonstrates that high plant density of 12.5 plants $\mathrm{m}^{-2}$ is adequate, at least for Bulwalana, under these conditions since grain filling proceeded normally.

Bulwalana averaged a leaf area index of 4.0 which was sufficient for the plants to intercept more radiation at higher plant densities; this, coupled with better water uptake, resulted in higher grain yields. In contrast, the higher LAI (about 6.0) of Bourgouri-28 at high plant density between 61 and 88 DAT did not result in greater radiation interception which reached its peak at a LAI lower than 6.0.

Studies conducted in northern Cameroon, observed that delayed transplanting of Muskwari sorghum caused yield reduction (unpublished data). The yield loss was attributed to reduced plant growth due to low soil moisture and photoperiodic response of these cold season sorghum varieties to the short days conditions. In these trials it was also shown that this crop has considerable plasticity in its ability to adjust to plant population changes. At lower plant densities, yield compensation was as a result of a higher percentage of plants bearing productive and bigger panicles. Results of this study also indicate that the crop was able to compensate for yield at low plant densities by producing bigger and well filled heads. These observations are in agreement with the findings of Myers and Foale (1981) who reported that in altering plant density the sink size is altered and the sorghum plant is able to compensate for this. Thomas et al. (1981) found that the major source of yield variation in their experiments was grain number. They indicated that sorghum compensates for low plant density by increasing grain number through the filling of more florests per panicle and the production of fertile tillers. 
This study demonstrated that the productivity of Masakwa sorghum could be improved by increasing plant density and use of early maturing varieties such as Bulwalana. Though the introduced variety, Bourgouri-28 produced more total biomass than the local variety Bulwalana, it partitioned more of this dry matter to the vegetative than to the reproductive parts since it is tall and late maturing. Increasing plant density to an optimal level can lead to a reduction in stem borer incidence on Masakwa sorghum. There is also a possibility for stem borer control using plant resistance since the two varieties had different levels of damage.

Future research needs. Since moisture is the limiting factor in dry season sorghum production, a study on the relation between root growth and water extraction will be useful. Results from such studies would be applicable in the aspects of simulating the effect of plant density on growth and yield, the relationship between the amount, depth and rate of water extraction and root length density. Also, since yield stability and reduction of risk of crop failure are of major concern to farmers in the Semi-Arid Tropics, simulation modelling could be used to examine a multitude of options under varying plant densities. The aim of this would be to improve and sustain productivity while minimising risks of crop failure due to water stress.

\section{ACKNOWLEDGEMENTS}

The authors are grateful to ICRISAT for providing a special fund for this work. The technical assistance of the late Mr. F. Ushie and Mr. Chris Aspotor is greatfully acknowledged. The authors thank Dr. B.R. Ntare for his helpful comments and discussion during the preparation of this manuscript.

\section{REFERENCES}

- A'Brook, J. 1964. The effect of planting date and spacing on the incidence of groundnut rosette disease and of the vector, Aphis craccivora Koch at Mokwa, Northern Nigeria. Annals of Applied Biology 54:199-208.

- A'Brook, J. 1968. The effect of plant spacing on the number of aphids trapped over the groundnut crop. Annals of Applied Biology 61:289-294.

- Barrault, J., Eckebil, J.P., and Vaille, T. 1972. Point des travaux de I'IRAT sur les sorghos repiques du Nord Cameroun. L'Agronomie Tropicale 27(8):791-814.

- Carsky, R.J. 1993. Survey of chemical characteristics of topsoil (0-30 cm) in dry season sorghum fields. TLU Technical Note No 10. National Cereals Research and Extension Project, Institute of Agronomic Research, Maroua, Cameroon.

- Djonnewa, A. and Dangi, O.P. 1988. Improvement of transplanted sorghum. In: Proceeding of the Third Regional Sorghum Workshop, 20-23 September 1988, Maroua, Cameroun, pp. 48-52.

- Farrell, J.A.K. 1976. Effects of groundnut crop density on the population dynamics of Aphis craccivora Koch (Hemoptera: Alphadidae) in Malawi. Bulletin of Entomological Research 66:317-329.

- Kanwar, J.S. and Virmani, S.M. 1987. Management of Vertisols for improved crop production in the Semi-Arid Tropics: A plan for technology transfer network in Africa. In: Proceedings of the First Regional Seminar on Management of Vertisols under Semi-Arid Conditions, 1-6 December 1986, Nairobi, Kenya. IBSRAM, Bangkok, Thailand, pp. 157-172.

- Lane, P.W. and Payne, R.W. 1996. GENSTAT for windows: an introductory course. Second Edition, Lawes Agricultural Trust, Rothamsted Experimental Station, UK.

- Myers, R.J.K.M. and Foale, M.A. 1981. Row spacing and population density in grain sorghum. A simple analysis. Field Crops Research 4:147-154.

- Njomaha, C. and Kamuanga, M. 1991. Le sorgho de saison seche en milieu paysan de l' Extreme Nord: Productivité et contraintes. Working Paper TLU/MA No. 3. National Cereals Research and Exension Project, Institute of Agronomic Research, Maroua, Cameroon.

- Pande, S., Harikrishnan, R., Alegbejo, M.D., Mughogho, L.K. Karunakar, R.I. and Ajayi, O. 1993. Prevalence of sorghum diseases in Nigeria. International Journal of Pest Management 39(3):297-303.

- Passioura, J.B. 1983. Roots and drought resistance. Agricultural Water Management 7:265-280.

- Rao, M.R. Ndikawa, R. and Singh, L. 1988. Progress of sorghum agronomic research in Far North Province of Cameroon. In Proceedings of the Third Regional Sorghum Workshop, 20-23 September, 1988, Maroua, Cameroon, pp. 53-66.

- Russell, M.B. 1980. Profile moisture dynamics of soil in Vertisols and Alfisols. In: Agroclimatology Research Needs of the Semi Arid Tropics (Patancheru: ICRISAT), pp. 75-87.

- Seetharama, N., Singh, S. and Reddy, B.V.S. 1990. Strategies for improving rabi sorghum productivity. In" Proceedings of Indian National Science Academy. B56 No. 5 \& 6, pp. 455-467.

- Swindale, L.D. and Miranda, S.M. 1984. The distribution and management in dryland agriculture of Vertisols in the Semi-Arid Tropics. In: The Properties and Utilization of Cracking Clay Soils. McGarity, J.W., Hoult, E.H. and So. H.B. (Eds.), pp. 316-323. Reviews in Rural Science 5, University of New England, Armidale.

- Thomas, G.A., Myers, R.J.K.M., French, M.U., Hall, B., Laewing, J.H. Dove, Taylor, G.K., Lehroy, E., Wylie, P. 
and Sterling, G.D. 1981. Evaluation of row spacing and population density effects of grain sorghum over a range of Australia environments. Australian Journal of Experimental Agriculture and Animal Husbandry 21:210-217.

- Tukahirwa, E.M. and Coaker, T.H. 1982. Effect of mixed cropping on some insect pests of brassicas reduced Brevicoryne brassicae infestations and influences on epigeal predators and the disturbance of oviposition behaviour in Delia brassicae. Entomologia Experimentalis et Applicata 32:129-140.

- Van de Berg, J., Van Rensburg, B.J. and Giliomee, J.H. 1991. The effects of plant density on the injuriousness of Busseola fusca (Filler) (Lepidoptera: Noctuidae) in grain sorghum. South African Journal of Plant and Soil 8(2): 85-87.

- Van Rensburg, B.J., Walters, M.C. and Giliomee, J.H. 1988. Plant population and cultivar effects on yield losses caused by the maize stalk borer Busseola fusca (Leptidoptera: Noctuidae) in grain sorghum. South African Journal of Plant and Soil 5:215-218.

(C)2002, African Crop Science Society

THE FOLLOWING IMAGES RELATED TO THIS DOCUMENT ARE AVAILABLE:

PHOto images

[cs02004t1.jpg] [cs02004f3.jpg] [cs02004f2.jpg] [cs02004f1.jpg] [cs02004f4.jpg]

\begin{tabular}{|l||l||l|}
\hline HOME & RESOURCES & MAILING LIST \\
\hline
\end{tabular}

